\title{
THE TWENTIETH-CENTURY REVOLUTION IN FAMILY WEALTH TRANSMISSION
}

\author{
John H. Langbein*
}

The ancient field of trust-and-estate law has entered upon a period of serious decline. In some law firms, even seasoned practitioners have begun to diversify away from the field. In leading circles of the trustand-estate bar, there is now open discussion of diminishing clientele, difficulty in billing for legal services at rates comparable to the rates for other specialties, and the reluctance of new associates to enter the field. ${ }^{1}$

Although it has been fashionable to attribute this decline to the dramatic 1981 revision of the federal transfer taxes, ${ }^{2}$ which effectively relieved the middle classes from entanglement with the estate tax, the theme of this article is that the phenomenon has causes far more profound. The decline of the probate bar reflects the decline of probate. The decline of probate has two quite different dimensions. One is the much-remarked rise of the nonprobate system. Financial intermediaries operate a noncourt system for transferring account balances and other property on death with little or no lawyerly participation. I shall recur to that subject in Part IV.

The decline of probate has another dimension that has not been well understood. Fundamental changes in the very nature of wealth have radically altered traditional patterns of family wealth transmission, increasing the importance of lifetime transfers and decreasing the importance of wealth transfer on death.

In this article I shall be concerned with private-sector wealth. ${ }^{3}$

* Max Pam Professor of American and Foreign Law, University of Chicago Law School. A.B. 1964, Columbia University; LL.B. 1968, Harvard University; LL.B. 1969, Ph.D. 1971, Cambridge University. - Ed.

This article elaborates upon remarks presented to the American College of Probate Counsel as the 1988 Joseph Trachtman Lecture. The research assistance of Kim Peirce and Nir Yarden and the suggestions of Walter Blum, Joel Dobris, Richard Epstein, Daniel Ernst, Lawrence Friedman, Mary Ann Glendon, and Robert Willis are gratefully acknowledged.

1. See, e.g., A. Forger \& M. Heckscher, The Trusts and Estates Lawyer in To. DAY's LaW Firm: Problems and Potential; or The T and E LAWyer: AN ENDANGEREd SpEcies? B-1, B-2 to B-3 (American College of Probate Counsel, 1987 Annual Meeting) (seminar outline).

2. Economic Recovery Tax Act of 1981, Pub. L. No. 97-34, 95 Stat. 172, Title IV, $\S \S 401-$ 442; see generally Dodge, The Taxation of Wealth and Wealth Transfers: Where Do We Go After ERTA?, 34 RUTGERS L. REV. 738 (1982).

3. More than twenty years ago in a notable law review article, Charles Reich called attention 
Into the eighteenth century, land was the dominant form of wealth. ${ }^{4}$ The technological forces that broke up older family-centered modes of economic organization called forth two new forms of private-sector wealth. One category is what we today call financial assets - that is, stocks, bonds, bank deposits, mutual fund shares, insurance contracts, and the like - which now comprise the dominant form of wealth. The other great form of modern wealth is what the economists call human capital. It is the skills and knowledge that lie at the root of advanced technological life.

The main purpose of this article is to sound a pair of themes about the ways in which these great changes in the nature of wealth have become associated with changes of perhaps comparable magnitude in the timing and in the character of family wealth transmission. My first theme, developed in Part II, concerns human capital. Whereas of old, wealth transmission from parents to children tended to center upon major items of patrimony such as the family farm or the family firm, today for the broad middle classes, wealth transmission centers on a radically different kind of asset: the investment in skills. In consequence, intergenerational wealth transmission no longer occurs primarily upon the death of the parents, but rather, when the children are growing up, hence, during the parents' lifetimes.

My other main theme, developed in Part III, arises from the awesome demographic transformation of modern life. For reasons that I shall explore, those same parents who now make their main wealth transfer to their children inter vivos are also living much longer. The need to provide for the parents in their lengthy old age has put a huge new claim on family wealth, a claim that necessarily reduces the residuum that would otherwise have passed to survivors. A new institution has arisen to help channel the process of saving and dissaving for old age: the pension fund. The wealth of the private pension system ${ }^{5}$ con-

to one species of "new property" - claims to government largess, especially those we have come to call entitlement programs, such as Social Security and Medicare. Reich, The New Property, 73 YALE L.J. 733 (1964). Reich's "new property" lies largely outside the scope of this article, because the entitlements he identified lie mostly outside family dominion. You can neither give nor sell nor bequeath your Social Security claims.

4. For example, data from Bucks County, Pennsylvania, indicates that realty constituted more than half of the wealth in seventeenth- and eighteenth-century probated estates. C. SHAMmas, M. SAlmon \& M. DAhlin, InHeritance in America From Colonial Times to the PRESENT 19 (1987) [hereinafter INHERTTANCE IN AMERICA]. For data evidencing a spectacular decline from colonial to modern times in the percentage of testators transmitting farms and firms, see $i d$. at 106, 191.

5. To be sure, the business of providing retirement income, both in money and in the form of medical services, is the prototypical government transfer scheme. Social Security benefits epitomize Charles Reich's "new property." Reich, supra note 3, at 734. But for propertied people, Social Security has always been something of a sideshow, and the recent revisions of the system 
sists almost entirely of financial assets. I shall emphasize a distinctive attribute of pension wealth, namely, the bias toward annuitization. When wealth is annuitized, virtually nothing is left for transfer on death.

Thus, wealth transfer on death is ever less characteristic of family wealth transmission. Part IV relates these great changes in family property relations to the residual process of wealth transfer on death.

At the outset, I must emphasize a pair of exclusions from the trends being described in this article. I shall be talking about the patterns of wealth transmission that characterize the broad generality of American wealth-holders - roughly, the upper third to upper half of the populace. I mean, in short, the middle and especially the uppermiddle classes, which is to say, the mostly white-collar, technical, managerial, and professional cohort. These people propel the knowledge-based economy of our post-industrial age, and they command much of its wealth. ${ }^{6}$ The trends I shall be discussing have had less influence upon the wealth transmission practices at the extremes of our society - among the very rich and among the poor.

The modes of gratuitous transfer have never had much relevance to the poor or near-poor. If you lack appreciable wealth, you will face many problems in life, but one problem that you will be spared is the question of how to transmit the wealth that you do not have.

At the other end of the spectrum, among those who populate the uppermost tail of the wealth distribution - people somewhere within the top one percent of wealth-holders - the trends that I shall be discussing have also not been of great significance. I shall have more to say about why the great forces canvassed in this article are largely spent before they touch dynastic wealth.

\section{Prologue: Family Wealth Then and Now}

It is often the case that the best way to broach the subject of the new is to identify the important characteristics of the old. In this instance, I begin by flipping the calendar backward a century and more, to the days when Abraham Lincoln lived on the American prairie and when his contemporaries were building the cities of the Atlantic seaboard, the Great Lakes, and the Ohio and Mississippi Valleys. We want to remind ourselves of some central traits of wealth holding and wealth transmission in this period.

that have begun to tax the benefits received by comparatively affluent distributees confirm that people of means will in the future have even less to expect from Social Security.

6. See text at notes 68-70 infra for discussion and interpretation of sector wealth data. 


\section{A. Family Property Relations in the Last Century}

The family was prototypically a unit of production. Nineteenthcentury America was overwhelmingly a nation of small farms. In the towns and cities, the predominant economic entities were small-firm producers and small shops. Farmers, artisans, and shopkeepers had in common the tradition that the entire family worked in the enterprise. In those circumstances, contemporaries had little occasion to distinguish between what we think of as earned income (income from one's labor) and investment income (the return to property). The two income streams were merged in a single endeavor. Both the generation of the parents and the generation of the children looked to the farm or the firm for their livelihood, with scant attention to idle accounting questions about how much of their income to apportion to labor and how much to property.

In emphasizing that the returns to labor and capital were composite, I do not mean that the property component was unimportant. Property was desperately important. Ownership of a farm or a firm rescued you from a mean life of stoop labor in someone else's field, mill, or household. In former times, it was vastly harder to live by your skills alone, without patrimony. Accordingly, people of means aspired to nothing so much as to leave their children similarly advantaged. You hoped to transmit the farm or the firm, and thus in the quaint phrase of the time, to make for your children "a provision in life."

There was relatively little formal education. ${ }^{7}$ This was a low-tech age, and the transmission of skills, like so much else, could still occur within the family. You learned your trade alongside your parents and your relations, in the fields, in the firm, or at the hearth. Put differently, the family was not only the primary unit of production, it was the primary educational entity as well. Only a few crafts and learned professions required external education; and even in those pursuits, education was frequently assimilated to a domestic model through the apprenticeship system of training.

Succession to ownership rights in this multigenerational enterprise occurred upon death - that is, upon the death of the parents, typically of the father. Various familiar arrangements were made for the widow, not only the common-law life estate known as dower, but also life interests in fee or in trust that could provide a larger fraction than

7. Little by comparison with today, not necessarily by comparison with education in the Old World; on the latter comparison, see B. BAILYN, EDUCATION IN THE FORMING OF AMERICAN SOCIETY (1960). 
dower and that could extend beyond realty. ${ }^{8}$ But the tendency both in intestacy and for testate estates was to limit the widow to a life interest, ${ }^{9}$ in order to assure continuity of the enterprise in the hands of the next generation, whose members had already been long employed in the enterprise.

Notice in this connection that widowhood was materially less common than today. I do not happen to have American data on this point, but I can report some German numbers gathered by a leading German scholar, Dieter Leipold. He found that as late as 1876-1880, for each 100 marriages that ended in death, the female survived in $56.5 \%$. By the year 1965, females were the survivor in $70 \%$ of marriages ending in death. ${ }^{10}$ Thus, over the century, female survivorship expanded from a modest probability to a probability that is better than two-to-one. The reasons, of course, are not hard to discern. There has been a precipitous decline in the rate of mortality associated with childbearing. Furthermore, while both sexes have benefitted from huge increases in longevity across the century, the advantage in favor of women has consistently expanded. ${ }^{11}$ Whereas spousal succession today is overwhelmingly a widow's business, in earlier times the wife was materially less likely to survive her husband than she is today; and when she did survive him, it was not likely to be for very long.

Accordingly, succession to the family farm or family firm typically occurred on the father's death. There was no reason for him to surrender dominion over the family patrimony inter vivos. Ownership until death reinforced parental control over the extended family and over its collective enterprise. Remember that although wealth transmission occurred on death, death occurred very much earlier than it does today. That is to say, succession on death occurred when both the parents and the children were younger than we now expect. This

8. In samples of colonial Virginia wills from the period $1660-1719$, the percentage leaving a life estate to the widow varied from a low of $21.1 \%$ to a high of $50 \%$. Deen, Patterns of Testation: Four Tidewater Counties in Colonial Virginia, 16 AM. J. LEGAL HisT. 154, 160 (1972). Lawrence Friedman studied a sample of New Jersey wills from the second half of the nineteenth century. He concluded that, by comparison with modern practice, "[p]erhaps the most striking feature of the [New Jersey] wills is the prevalence of trusts and future interests." Friedman, Patterns of Testation in the 19th Century: A Study of Essex County (New Jersey) Wills, 8 AM. J. LEGAL HIST. 34, 41 (1964). "In 1850 the number of wills which made at least some non-fee disposition for the widow was more than twice that of wills which made fee dispositions only." Id. at 42-43. By 1900, this pattern had changed markedly. "Thus the earlier the will in [Friedman's sample], the more likely it was to make non-fee gifts to the wife." Id. at 43.

9. See INHERITANCE IN AMERICA, supra note 4, at 32-33 (intestacy and forced share), 51-53 (testamentary provision in Bucks County, Pennsylvania, 1685-1756).

10. Leipold, Wandlungen in den Grundlagen des Erbrechts?, 180 ARCHIV FüR DIE CIVILISTISCHE PRAXIS 160, 186 (1980).

11. Id. at 187. For American data on the greater enhancement of female life expectancy in the twentieth century, see text at notes 58-59 infra. 
difference is, of course, no mystery. It results from the awesome change in life expectancy over the past century, a fascinating subject about which more is said in Part III. Thus, even though wealth transfer in the previous century tended to occur on death rather than inter vivos, decedents were less often elderly. The successors were typically young adults, as compared to the middle-aged children who typically succeed when parents die in modern circumstances.

Finally, to complete this snapshot of important traits of nineteenth-century wealth transmission patterns, I wish to say something about the diminished expectations of daughters. Perhaps the easy way to make this point is to remind you how often you have come across some family firm from earlier times in which the father associated the son or sons in the firm's name - for example, Steinway \& Sons; but you have not seen firms called Steinway \& Daughters. Although there were many exceptions, the wealth transmission process tended to favor the male line. ${ }^{12}$ The firm or the farm had to be worked. Except when a family had only a daughter or daughters, continuity within the patrimony emphasized the son. ${ }^{13}$

\section{B. Family Property Relations in Modern Times}

In the late twentieth century, the family has in general ceased to be an important unit of production. To be sure, you can still find dribbles of cottage industry in America, and there is still a fair amount of Mom-and-Pop retailing, but in the main the production and sale of goods and services has forever left the home. The technological sophistication and marketing complexity of modern modes of production and distribution impose enormous capital requirements. Village

12. For evidence of paternal "discrimination" against daughters in a smallish sample of Bucks County, Pennsylvania, probated estates from the period 1685-1756, see INHERITANCE IN AMERICA, supra note 4, at 44-47. Colonial Virginia data shows that the devise of fee-simple land to daughters was a "rarity"; daughters were much more likely to be devised household personalty and farm animals. Deen, supra note 8, at 159-60. A study of 636 Wisconsin farms that remained within the family (that is, were transmitted to descendants of the first owner) during the century from 1848 to 1948 discerns a strong preference for sons over daughters. The 636 farms were transferred 1,458 times. Of these transfers, $74.6 \%$ were to sons, $3.6 \%$ were to sons and daughters jointly, $14.5 \%$ were to daughters, and $7.3 \%$ were to relatives other than children. Tarver, Intra-Family Farm Succession Practices, 17 RuRAL Soc. 266, 267-69 (1952). "[A] farmer usually finds it more appropriate to transfer his farm to a son, who may have farmed with him for several years, than to a daughter and son-in-law." Id. at 269.

13. In emphasizing this reason for preferring the male line, I do not wish to imply that it was the sole factor. Conceptions that we now find archaic about the needs and roles of women were also involved. But it is instructive to see that in INHERITANCE IN AMERICA, supra note 4, (which is fully informed by modern feminist sensibilities), the authors point out that by the end of the nineteenth century, when the transmission of family enterprise had become markedly less common, id. at 106, the treatment of sons and daughters in the authors' Bucks County, Pennsylvania, sample became "nearly identical." Id. at 108. 
blacksmiths cannot manufacture automobiles, airplanes, and oil rigs. The village entrepreneur can still sell a screwdriver or make a hamburger, but the evidence is overwhelming that the customer mostly prefers to patronize K-Mart or McDonald's. Thus, the characteristic unit of production in our age is corporate rather than domestic, it is the share company.

These trends extend to farming as well. American agriculture is ever more technology driven and capital intensive. It has become a byword that we live in an era of corporate agriculture. Family farms still exist in America, indeed, in some farming areas it would be fair to say that family farms remain characteristic. But a large fraction of them are hobby farms, secondary enterprises conducted by people whose main livelihood derives from employment outside the home. As farms have grown in size and productivity, an astonishing agricultural depopulation has occurred. In what used to be a nation of farmers, we are now fed by a mere $5 \%$ of the population, down from $44 \%$ in 1880,14 and it should be remembered that these people are not only feeding the rest of us, they are running our largest export industry as well.

Thus, in the main, we neither farm nor manufacture at home. The family has undergone a specialization of function. In economic terms, the family remains a unit of consumption but no longer a unit of production. Enterprise is organized outside the home, and the worker now leaves the home for his employment. Such a worker contributes his labor to his employment, but he no longer supplies the plant and equipment as he did in the bygone day of the family enterprise. The reason that most workers use external capital is, of course, closely connected to the technological and marketing forces that have magnified the size and complexity of the productive processes, the forces that drove the worker out of the home in the first place. Modern modes of enterprise are capital intensive. The blacksmith could afford his anvil, but we cannot expect the autoworker to supply his factory or the airplane pilot to bring along his own Boeing 747.

The ever-larger capital requirements of technologically advanced enterprise required modes of financing that exceeded the capabilities of the family. Ownership of a small firm or a small farm could lie within the scope of family-based capital accumulation and capital transmission, but we understand why IBM, General Electric, and AT\&T cannot be family firms. ${ }^{15}$ The corporate form arose to facilitate the

14. 1 Historical Statistics of the United States, Colonial Times to 1970 ser. $\mathrm{K} 1$ 16, at 457 (1975) [hereinafter HisTORICAL STATISTICs].

15. See Daniel Bell's remarks about the "breakup of family capitalism" at the end of the 
pooling and allocation of capital, as did the specialized institutions of finance. In the late twentieth century we recognize three dominant modes of financial intermediation: first, the corporation, and with it, the securities industry that makes the market in corporate shares and corporate debt; second, banking - commercial, investment, and savings and loan; and third, the insurance industry. All three were primitive in antebellum America. ${ }^{16}$ Not only have these financial intermediaries now displaced the family's role as the unit of capital accumulation, they have also created the new forms of wealth in financial assets - the various securities, depositary claims, and other contract rights.

These instruments of financial intermediation now absorb the savings that the family previously devoted to the family enterprise. Because family wealth is no longer retained but rather invested externally, it now takes the form of claims on outside enterprises. These financial assets have become the characteristic form of transmissible wealth. It is the stuff of the financial pages. As Roscoe Pound said in an arresting dictum, "Wealth, in a commercial age, is made up largely of promises." 17 I shall have more to say about how the prevalence of financial assets has altered the patterns of family wealth transmission. For the present, however, I want to direct attention to that other species of new property that is associated with the breakup of the family as a unit of production: human capital.

\section{Wealth Transfers Through Human Capital}

The same underlying technological and economic forces that caused the dissolution of family-based enterprise have also stripped the family of much of its role as an educational institution. This development, which is in a sense quite obvious to us all, has had enormous implications for family wealth transmission, implications that have not been adequately appreciated.

It is a truism that a technological age requires a technologically proficient workforce. The awesome expansion of human knowledge

nineteenth century, when bankers and later corporate managers gained control of large enterprises. D. Bell, THE END OF IDEOLOGY 40-42 (1960).

16. See R. Seavoy, The Origins of The American Business Corporation, 1784-1855 3-7, 191-223 (1982) (spread of industry-specific general incorporation statutes in New York in $1840 \mathrm{~s}$ and $1850 \mathrm{~s}$ ). The marketability of corporate shares increased significantly from the $1890 \mathrm{~s}$. See Navin \& Sears, The Rise of a Market for Industrial Securities, 1887-1902, 29 Bus. HIST. REv. 105 (1955). For an overview of the history of American banking, see Green, Financial Intermediaries, in 2 ENCYCLOPEDIA OF AMERICAN ECONOMIC HISTORY 707 (G. Porter ed. 1980). A recent study of the history of the life insurance industry is V. ZELIZER, MORALS AND MARKeTS: The Development of Life INSURANCE IN THE UNITEd STATES (1979).

17. R. Pound, AN Introduction to the Philosophy of LaW 236 (1922). 
over the past century and more has made the family obsolete as a repository and transfer agent for this huge range of knowledge. In olden times, I have said, you learned your trade at home and hearth, or else in apprenticeship to a neighbor. Only a handful of callings required training beyond these domestic patterns. Today, by contrast, we have gone so far in the opposite direction - toward externalizing education - that we even send people outside the home to prepare for life in the home. (I refer not simply to the study of what is called home economics, but to our ever-greater reliance upon the schools for basic acculturation.)

\section{A. Educational Expenditure}

The educational demands of modern economic life have become immense, and so has the cost of providing children with this educational endowment. A central thesis of this article is that paying for education has become the characteristic mode of intergenerational wealth transmission for most American families.

Look at the statistics in order to get a sense of the underlying magnitudes. Total expenditures for formal education in the United States in 1840 have been calculated at $\$ 9.2$ million. ${ }^{18}$ This sum increased over the nineteenth century, a period of relatively low inflation, to stand at $\$ 289.6$ million in 1900.19 By 1959 the figure had reached $\$ 23.9$ billion, which amounted to $4.8 \%$ of gross national product. ${ }^{20}$ Less than thirty years later, in the 1986-1987 academic year, the total expenditure on formal education stood at $\$ 282.1$ billion, a figure that represented $7 \%$ of gross national product. Of these amounts, $60 \%$ went to fund primary and secondary education, $40 \%$ went to higher education. ${ }^{21}$

While the official educational statistics are valuable for conveying a general sense of the magnitudes, they conceal many subtle issues of definition and measurement. Many sins pass under the label of education. Not every course in basketweaving deserves to be reckoned as investment in human capital. On the other hand, much of our financial investment in our children takes forms that, somewhat arbitrarily, fall outside the category of formal education. If you take your children to a nature preserve or on a tour of French cathedrals, that's

18. Fishlow, Levels of Nineteenth-Century American Investment in Education, 26 J. ECON. Hist. 418, 420 (1966). See id. at 431 for inflation-adjusted figures in 1958 dollars.

19. Id. at $420,431$.

20. Center for Education Statistics, Digest of Education Statistics 1987, at 24 (1987) [hereinafter EdUCATION Digest].

21. Id. at 4,25 . 
private recreation, whereas when some educational institution takes your kid square dancing, that's education. Indeed, as my colleagues Walter Blum and the late Harry Kalven pointed out in a celebrated book some thirty years ago, the most important inheritance of all the thing that decisively advantages middle-class children - is the cultural bequest from their parents. ${ }^{22}$ That parental transfer of language, of values, and of psychological well-being sets the stage for all the formal learning and achievements of later years. None of that gets captured in the educational statistics. Nevertheless, once due allowance is made for the shortcomings of what the statisticians deem to be education, the numbers are so enormous that they bespeak an enterprise of daunting importance.

In 1870 only $2 \%$ of the population was graduating from high school; by 1970 the figure was $75.6 \% .^{23}$ In 1870 institutions of higher learning in the United States conferred a total of 9,372 degrees, of which 9,371 were bachelor's degrees and exactly one was a doctorate. In 1970 the total number of degrees conferred showed an increase of more than a hundredfold over 1870. The figure stood at $1,065,000$, of which almost 30,000 were $\mathrm{Ph} . \mathrm{D}$. or equivalent degrees. ${ }^{24}$ College enrollments as a percentage of the college age population reached $12.5 \%$ in $1946,{ }^{25} 29.6 \%$ in 1970 , and $31.3 \%$ in $1985 .{ }^{26}$ As recently as 1940 , only $4.6 \%$ of the American population had completed four or more years of university study. By 1985, almost $20 \%$ (19.4\%, to be precise) had done so. ${ }^{27}$

Economists who have examined this gigantic education industry have increasingly been of the view that expenditures on education ought not to be viewed as a simple consumption expense, like money spent on corn flakes or handkerchiefs. ${ }^{28}$ Rather, they see educational expenditure as an investment, closely akin to conventional investment in plant, equipment, and inventory. Education produces skills, and skills are as much an input in the productive process as machines. Economists now routinely liken these skills to capital, the species of capital that they call human capital. Modern productive processes are

22. W. Blum \& H. Kalven, The Uneasy Case for Progressive Taxation 88 (1953).

23. Historical STATistics, supra note 14, ser. H 598-601, at 379.

24. Id., ser. H 751-765, at 385-86.

25. Id., ser. $\mathrm{H} 700-715$, at 383 .

26. U.S. BuReau of the Census, Statistical Abstract of the United States 1987 118, table 192 (1987) [hereinafter STATISTICAL ABSTRACT] (school enrollment figures for those 18-24 years old).

27. Id. at 121, table 197.

28. See, e.g., Campbell \& Siegel, The Demand for Higher Education in the United States, 1919-1964, 57 AM. ECON. REv. 482 (1967). 
skill-driven. Whether we speak of new fields like aeronautics or ancient ones like health care, the story is the same. While plant and equipment become increasingly sophisticated - robotics and computers and CAT scanners and all that - the skills of the workforce become still more decisive. Human capital thus substitutes for nonhuman capital. Skill embodies knowledge, and new knowledge not only displaces old knowledge, it displaces plant and equipment as well. Think of the advance in medical science that made polio a preventable disease and consigned the iron lung industry to the scrapheap: Skill displaced machines.

Human capital, being literally embodied in mortals, is distinguished from physical capital by the frailty of the human condition. Human capital dies with the holder and thus needs to be created afresh in each generation. Of course, the highly transitory quality of human capital is really more a difference of degree than of kind. Machines and structures also fall apart or become obsolete, which is why we systematically account for the artifacts of physical capital by means of depreciation schedules.

Careful econometric study has documented that human capital has steadily increased over the twentieth century as a fraction of total capital and as a fraction of gross national product. The percent of GNP spent on both education and on job training grew by $80 \%$ from 1929 to 1969 , in which year it stood at $15.4 \%$ of GNP. ${ }^{29}$ A recent set of calculations "implies that education costs society approximately as much as investment in nonresidential physical capital."30

There is no mystery about who has been paying the bill for this vast expansion of education. Even allowing for some scholarships, loans, and student labor, the main burden falls upon the parents. Indeed, even childless people pay substantial sums in taxes to support the public educational establishment. But for present purposes, the focus is upon propertied families who are raising children.

My thesis is quite simple, and, I hope, quite intuitive. I believe that, in striking contrast to the patterns of last century and before, in modern times the business of educating children has become the main occasion for intergenerational wealth transfer. Of old, parents were mainly concerned to transmit the patrimony - prototypically the farm or the firm, but more generally, that "provision in life" that rescued children from the harsh fate of being a mere laborer. In today's economic order, it is education more than property, the new human

29. J. Kendrick, The Formation and Stocks of Total Capital 71 (1976).

30. Johnson, Investment in and Returns from Education, in THE LEVEL AND COMPOSITION of Household SAVING (P. Hendershott ed. 1985). 
capital rather than the old physical capital, that similarly advantages a child.

We know that income levels correlate powerfully with education. In 1985 the median annual income of full-time male workers aged twenty-five and over who had completed some years of high school but had not graduated was under $\$ 20,000$; for those who had completed four years of college the figure was above $\$ 30,000$; and for those with more than four years of college, the figure approached $\$ 40,000$. The comparable earnings figures for female workers were lower, but differences in educational attainment among women produced similar disparities in favor of the well educated. ${ }^{31}$

Family wealth and its corollary, family income, are crucial determinants of access to education. A sociologist of education recently summed up the data in the following way: "The amount of schooling that individuals obtain and their school continuation decisions are strongly affected by characteristics of their families. Persons whose parents have more schooling, higher income, and better jobs; whose families are smaller; and who were raised in urban areas typically obtain more schooling than persons from less-advantaged backgrounds." 32

The process of delivering educational advantage to children begins when they are very young. There has been a huge increase in formal preschool education in recent decades. ${ }^{33}$ In the years of primary and secondary education, propertied parents strive to locate in suitable school districts, or to send their children to private schools. By the way, the distinction between private and public schools is far less meaningful than might appear at first glance. Many of those distinguished suburban school districts that represent the high-water mark of quality in our public school tradition are in truth better understood as private schools with tax-deductible tuition - the tuition taking the form of relatively high real estate taxes that are deductible against income taxes. ${ }^{34}$ Parents tend to move into these school districts when

31. EduCATION DigesT, supra note 20, at 283. The Wall Street Journal recently reported data indicating much wider income disparities across the categories of educational attainment. Average monthly income for a person with only a high-school diploma is shown as $\$ 415$; a vocational degree, $\$ 990$; a bachelor's degree, $\$ 1,540$; a doctoral degree, $\$ 2,747$; and a professional degree, \$3,439. Wall St. J., Mar. 17, 1988, at 21, col.3.

32. Mare, Trends in Schooling: Demography, Performance, and Organization, 453 ANNALS 96, 101 (1981).

33. Education Digest, supra note 20, at 4, 12.

34. See Ellickson, Cities and Homeowners Associations, 130 U. PA. L. REv. 1519, 1574-75 (1982) (discussion of tax inducements for governments to perform services in competition with nongovernmental entities). 
they have school-age children, and to move out when they no longer need the schools.

And then there is college. The federal government's Digest of Education Statistics 1987 reports that the average annual charge for tuition, room, and board for undergraduates in the 1985-1986 academic year was $\$ 3,640$ at public colleges and $\$ 8,870$ at private colleges. ${ }^{35}$ Because these numbers are averages, which lump low-cost local institutions with elite schools, they understate the bills that parents face when they send children to the major universities. At the premier private universities, the bill for tuition, room, and board now exceeds $\$ 15,000$ a year; travel and incidentals can easily bring the figure to $\$ 20,000$. In the graduate and professional schools, the price tag is higher still. This year, most of the major private law schools are charging about $\$ 13,000$ in tuition alone. Tuition, fees, books, and supplies at the University of Chicago Law School this academic year are estimated to cost $\$ 13,550$. At Chicago, we project total annual expenses for an unmarried law student at more than $\$ 21,000$ per year, which puts the effective price tag of a three-year Chicago degree at about $\$ 65,000.36$ By the way, it costs us a further $\$ 35,000$ to deliver that degree to the student, money that comes from endowment income, a trickle of foundation and government grants, and a torrent of alumni support.

A story in Newsweek in May of 1987 used figures on the annual cost of undergraduate education at Johns Hopkins. The $\$ 15,410$ that Johns Hopkins charged in 1987 for tuition, room, and board constituted $31 \%$ of a family income of $\$ 50,000$ per year. By contrast, the $\$ 2,000$ that Johns Hopkins charged in 1960 represented only $15 \%$ of the inflation-adjusted equivalent family income for 1960, which was $\$ 13,505.37$

Now it is quite obvious that very few families can afford to pay $31 \%$ of family income, or anything near it, on what we would call in an accounting sense - a current basis. That is especially true when the family has more than one child in the educational mill at the same time. For most families, therefore, these education expenses represent capital transfers in a quite literal sense: The money comes from savings, that is, from the family's capital; or debt is assumed, meaning that the money is borrowed from the family's future capital.

The guidelines that the universities use for calculating financial aid

35. EdUCATION DIGEST, supra note 20, at 117.

36. University of Chicago LaW SCHOOL, ANNOUNCEMENTS 52 (1987-1988).

37. Fuming over College Costs, NewsweEk, May 18, 1987, at 66 [hereinafter Newsweek]. 
are quite explicit about taking into account all family wealth, not just current income, in deciding what fraction of the education bill the family should be made to pay. At the law school level for example, we are served by an organization called the Graduate and Professional School Financial Aid Service, known under its repulsive acronym of GAPSFAS, which analyzes the family financial statements of applicants. GAPSFAS guidelines treat as available for defraying educational expenses not only the family's liquid assets, but also the family's home equity and the net worth of any family farm or family business. GAPSFAS publishes tables that indicate what percentage of home equity or of business or farm net worth should be utilized before the student qualifies for financial aid. These tables resemble the progressive bracket tables in the Internal Revenue Code: the greater the family wealth, the higher the fraction that the parents are expected to transfer to the child in support of the child's education. ${ }^{38}$

The same Newsweek article that discussed the education cost figures from Johns Hopkins recounted the saga of a parent named C.Y. Lu, who presently has the financial misfortune to have one son attending Princeton while the other is at the Harvard Law School. $\mathrm{Mr} . \mathrm{Lu}$ is reported to have sold off investments, taken out educational loans, and refinanced his home mortgage by $\$ 60,000$, in order to raise a total of $\$ 140,000$. Mr. Lu is quoted as saying, "I've told my sons, your education is going to be your inheritance." 39

There in Mr. Lu's words you see my theme encapsulated. Education is displacing inheritance, lifetime transfers are displacing succession on death. Back in the nineteenth century or earlier, Mr. Lu would have husbanded his wealth and left it to his sons at his death. Today, in mid-life, he cashes out and goes into debt in order to fork over his savings to Princeton and Harvard.

Nobody forces Mr. Lu to do this. It was quite open to him to say to his two sons, "Boys, I'll make you a deal. I'll buy you out of those admission letters from Princeton and Harvard. Stay away from those cauldrons of red ink, and content yourselves with attending the community college down the road - or better yet, go right to work in an accessible career like pumping gas at the corner filling station. Then, I'll have $\$ 140,000$ more in family wealth that I can invest through Merrill Lynch. It will compound and be available for you on my death." Well, we all know that virtually no parent behaves that way.

38. See H. Flamer, D. Horch \& J. Bruno, Measuring the Financial Status of Graduate and Professional Students: GAPSFAS Theory and Computation ProceDURES, 1987-88 AWARD YEAR 9, 22-23, 48 (1987).

39. NEwSWEEK, supra note 37, at 67. 
Parents understand full well the point that the economists have been demonstrating with their studies of human capital. Those degrees from Princeton and Harvard are superior investments when compared to any class of financial assets, by virtue of a very conventional test: The degrees produce a far larger income stream.

$\mathrm{Mr}$. Lu happened to have sons, but if his children had been daughters, his financial predicament would scarcely have improved. One of the grand American social achievements, in which we led the world, was to extend the opportunity for formal education to women. That trend was epitomized in the nineteenth century by the proliferation of women's colleges. Today, more women than men attend college. ${ }^{40}$ Accordingly, the twentieth-century revolution in family wealth transmission may ultimately come to be understood as having been even more consequential for women than for men. ${ }^{41}$

From the proposition that the main parental wealth transfer to children now takes place inter vivos, there follows a corollary: Children of propertied parents are much less likely to expect an inheritance. Whereas of old, children did expect the transfer of the farm or firm, today's children expect help with educational expenses, but they do not depend upon parental wealth transfer at death. Lengthened life expectancies mean that the life-spans of the parents overlap the lifespans of their adult children for much longer than used to be. Parents now live to see their children reaching peak earnings potential, and those earnings often exceed what the parents were able to earn. Today, children are typically middle-aged when the survivor of their two parents dies, and middle-aged children are far less likely to be financially needy. It is still the common practice within middle- and uppermiddle-class families for parents to leave to their children (or grandchildren) most or all of any property that happens to remain when the parents die, but there is no longer a widespread sense of parental responsibility to abstain from consumption in order to transmit an inheritance.

\section{B. Consequences for the Ethos of Inheritance}

At the outset of this article, I cautioned that the revolution in family wealth transmission would be seen to be less significant for dynastic wealth holders. School bills make little dent in large fortunes. There are intrinsic limits to how much education an individual can absorb,

40. See Statistical ABSTRACT, supra note 26 , at 137, tables 231-232.

41. See notes 12-13 supra and accompanying text. 
and those limits are reached long before the holders of great wealth would notice.

Nevertheless, there is a deeper sense in which the forces that have transformed the patterns of wealth transmission for the broad middle classes have also touched the holders of great wealth. The new pattern has become a social norm, a norm so powerful that it has begun to chip away at the ethos of older notions of inheritance.

This is a phenomenon that I first became aware of as a result of talking with practicing estate planners. Recently, I noticed Fortune magazine running a story on it. Fortune reported on the thinking of some extremely wealthy people who planned to leave their children only token inheritances. The story led off with the views of Warren Buffett, chairman of the Berkshire Hathaway holding company, whose personal wealth is estimated at $\$ 1.5$ billion. Buffett is quoted as explaining why he plans to leave each of his three children only a few hundred thousand dollars. Having put the children through college, Buffett says he expects them "to carve out their own place in this world." It would be "harmful" and "antisocial" to set up his children with "a lifetime supply of food stamps just because they came out of the right womb." 42 Buffett's $\$ 1.5$ billion will go to charity. So will the $\$ 50$ million fortune of a New York entrepreneur named Eugene Lang, who sent his three children to college, gave each "a nominal sum" after college, and plans to disinherit them. He explained to the Fortune reporter: "To me inheritance dilutes the motivation that most young people have to fulfill the best that is in them. I want to give my kids the tremendous satisfaction of making it on their own."43

People like Messrs. Buffett and Lang are quite exceptional. Most people of great means prefer to leave most of their wealth to their descendants, hoping to shape the younger generations so that the wealth will be used responsibly. The hostility towards conventional succession expressed by Messrs. Buffett and Lang is noteworthy not because such hostility is prevalent, but simply because it would have been inconceivable a century or more ago. Can we imagine the twelfth Earl of Carlisle arranging for the dissipation of the family seat, in order to stimulate the thirteenth Earl to the challenge of reacquiring it?

Messrs. Buffett and Lang are voicing an attitude toward conventional wealth transmission that is not only quite exceptional, it is historically very recent and also very American. Behind it, I think, are two novel ideas. One is the assumption that wealth is largely fungible,

42. Kirkland, Should You Leave It All to the Children?, Fortune, Sept. 29, 1986, at 18.

43. Id. at 21. 
that there is no great sentimental attachment nor any particular social significance to the family's existing patrimony. That is why Mr. Buffett could liken his fortune to a pile of food stamps, and why Mr. Lang could hope that his children would experience the satisfaction of "making it on their own." By it, he means, something like it, but not the identical property. This notion that wealth is fungible is an idea that fits the new forms of wealth better than the old, an idea that fits American circumstances better than English or European. You're much more likely to be sentimental about your ancestors' manor house than about the family's portfolio of marketable securities.

Further, the disdain for customary modes of wealth transfer that Messrs. Buffett and Lang are voicing presupposes that these gentlemen have already achieved for their children the characteristic wealth transfer of modern times, the investment in human capital through education. More and more, Americans expect personal wealth to take the form of earned income, that is, we expect it to be a return on human capital. Messrs. Buffett and Lang have taken that expectation to its limit; in their eyes, conventional wealth transfer has lost its legitimacy. The esteem associated with holding property really now applies only to earned income, to property that embodies the fruits of human capital. In this sense, the revolution in family wealth transmission, which is overwhelmingly an event of the broad middle classes, touches even the holders of great wealth.

\section{Europe and England: A Comparative Aside}

The substitution of human capital for older forms of property is less evident in the patterns of family wealth transmission in Europe than in the United States, even though the underlying technological and economic forces have been broadly comparable on both sides of the Atlantic. The main explanation surely has to do with differences in educational finance. As a generality, the Europeans have socialized education and educational finance much more than we.

England represents something of a middle case, because of the enormous importance of private, pre-university schooling in the English system. Propertied English families are just as prepared to sacrifice for Eton or Winchester as Americans are for Stanford or Dartmouth. On the other hand, this kind of private schooling is unimportant on the Continent; and both in England and on the Continent, the university systems are all but wholly socialized. Tuition is mostly negligible, and because the state tends to suppress quality differentials among universities, students are more likely than in the United States to live at home and attend the local institutions. 
For Europeans, therefore, educational finance is not the cataclysmic event in family fortunes that it is for Americans. I do not want to overstate this point. It is far costlier for a European family to keep a child at home and in university than to send him out into the workforce. That is one reason why, there as here, levels of participation in higher education correlate strongly with levels of family income. There as here, education is costly, and paying for it means that less wealth will be available for other purposes. But in Europe the intermediation of the state distorts the process more and makes the phenomenon more difficult to discern. In Europe more of the wealth transfer becomes a branch of tax economics. Europeans pay materially higher taxes than Americans, and these taxes, which subsidize higher education as well as many other services, necessarily result in lower marginal incomes and lower accumulations of family wealth than would otherwise be the case. This is, of course, a difference of degree rather than of kind, since most of American education, both preparatory and university, is publically operated and tax-subsidized. But as is often the case in matters of economics, differences at the margin matter a great deal. The United States is unique among advanced countries in the extent to which educational finance remains privatized, especially the kinds of education that are most sought-after by the upper-middle classes. ${ }^{44}$

\section{The Pension Revolution}

The other great chapter in the saga of fundamental change in family wealth transmission being told in this article concerns the phenomenon of retirement and the rise of the private pension system. Pension funds are another artifact of the new forms of wealth that arose in consequence of the breakup of older, family-centered modes of production. Neither on the prairie nor in the cities of Abraham Lincoln's day had anybody ever heard of a pension fund. Your life expectancy was such that you were unlikely to need much in the way of retirement income. If you did chance to outlive your period of productive labor, you were in general cared for within the family.

Not only is the need for a retirement income stream relatively recent, but so too is the mode of wealth that now supplies it. Pension funds are composed almost entirely of financial assets - the instruments of financial intermediation - that distinctively modern form of property that was still of peripheral importance in the last century.

44. See EDUCATION Digest, supra note 20 , at 120 , for percentage of American university budgets deriving from tuition revenue. 
As late as World War II, the private pension system was minuscule. ${ }^{45}$ Today, the assets of nonfederal pension plans (that is, private plans plus the pension funds of state and local government employees) total approximately two trillion dollars. ${ }^{46}$ As of 1984, pension funds owned $22.8 \%$ of equity securities in the United States and about half of all corporate debt.47 For many middle- and especially upper-middle-class families, pension wealth is their largest asset. But pension wealth has traits that mark it off sharply from traditional property, especially when we look at it from the standpoint of family wealth transmission.

\section{A. The Enhancement of Life Expectancy}

The way to begin thinking about the pension revolution is to grasp the magnitude of the underlying demographic phenomena that brought it about. Life expectancy a hundred years ago was about forty-five years. Today, it is seventy-five years and climbing. ${ }^{48}$

Behind the awesome spurt in life expectancy over the last century or so is a phenomenon that has been called "the elimination of premature disease." 49 In a nutshell, the insight is that diseases belong in two categories - the infectious or acute diseases that we have now largely banished from the mortality tables; and those diseases of old age that appear to set intrinsic limits on human longevity. Some researchers think that they see age eighty-five as the approximate eventual norm of the human life span. In 1980 white females were living to within seven years of that ideal. Three of those seven years of what is called "average premature death" are accounted for by violent death - automobile accidents, bathtub falls, and so forth. Thus, from the medical viewpoint, it is being said that the "task of eliminating premature death ... has been largely accomplished." 50

To understand what modern sanitation and modern medicine have achieved, it is instructive to consider the case of tuberculosis, which in the year 1840 was the leading cause of death in the United States. As late as the year 1900, one American in five hundred died from tuberculosis every year. ${ }^{51}$ By 1970 , mortality from tuberculosis had decreased

45. See W. Greenough \& F. King, Pension Plans and Public Policy 27.67 (1976).

46. Pension Assets Total Nearly \$2 Trillion, 13 Pens. Rep. (BNA) 1918-19 (Nov. 17, 1986).

47. R. Ippolito, Pensions, Economics and Public Policy 123-24 (1986).

48. See Dychtwald, The Aging of America: Overview, in Wellness and Health PromoTION FOR THE ELDERLY 1 (K. Dychtwald ed. 1986).

49. Fries \& Crapo, The Elimination of Premature Disease, in Wellness and Health ProMOTION FOR THE ELDERLY, supra note 48, at 19.

50. Id. at 26.

51. Id. at 19. 
by over $99 \% .^{52}$ Many factors account for this decline in tuberculosis mortality rates, including pasteurization of milk, inspection of cattle, improvement in nutrition and in living conditions, and the quarantine of diseased persons. "Epidemiologists are fond of pointing out that about nine-tenths of the present improvement . . . occurred even before the discovery of any drugs that could kill the tuberculosis germ. Streptomycin was the first such drug, and it was first used in the late 1940s." 53

Declines in the mortality rates from other dread infectious diseases have been as dramatic. "Smallpox is eliminated entirely. Paralytic polio, diphtheria, tetanus, typhoid ... and whooping cough have been reduced to negligible levels. Deaths from measles and from streptococcal infections have been eliminated, even though the diseases themselves still occur." ${ }^{4}$ Against the power of penicillin syphilis can no longer kill. "All these conditions have declined over 99 percent, and in some cases, 100 percent[.]" 55

Part of what makes the AIDS epidemic so haunting is that it has happened against this background of utter triumph over earlier forms of infectious disease. What we cannot yet know is whether AIDS will remain an exception in a world where other infectious diseases remain insignificant; or whether the elimination of the ancient infectious diseases has set the stage for the development of new ones that, like AIDS, are resistant to the environmental measures and to the antibiotics that vanquished the old ones.

Roughly three of every four deaths in the United States today stem from three causes: cardiovascular disease, cancer, and automobile accidents. The prominence of cardiovascular disease and cancer as killers is related to the elimination of infectious diseases. "Survival from the diseases that used to kill early in life allowed the illnesses that occur later in life to increase in frequency as a cause of death." 56

I have travelled (I hope not detoured) into this demographic data, because I think that without it one cannot really grasp what the pen-

52. Id. at $19-20$.

53. Id. at 20.

54. Id. at 21.

55. Id. For pneumonia and influenza,

the reduction has been only 85 percent. However, this statistic hides an equally dramatic result. Pneumonia and infuenza deaths now occur almost exclusively among infirm, very old, or already ill individuals. Such deaths, which are attributed to a germ, in fact result from diminished defense mechanisms and lost organ reserve. Deaths from these conditions in otherwise healthy individuals in the early and middle years of life have declined by the same 99 percent as the other infectious diseases.

Id.

56. Id. at 22 . 
sion revolution is all about. The pension fund is a direct response to the new demographics, in the setting of the new property. That point is best made if we return for a moment to our baseline in antebellum America, in order to see how the phenomenon of aging transpired when family wealth relations centered on the common patrimony in farm or firm.

Why were there no pension funds? The most important explanation is that, on account of the lower life expectancy of the times, far fewer people outlived their period of productive employment. You were, so to speak, much more likely to die with your boots on. I do not want to exaggerate this point. The forty-five-year life expectancy that prevailed a century ago is a composite figure, greatly distorted by infant mortality. ${ }^{57}$ Your chances of surviving to a reasonable age were much enhanced in the last century once you had navigated the shoals of infancy. A white male who lived to age twenty in the year 1900 had an ultimate life expectancy of 62.2 years; a white female aged twenty in 1900 had a life expectancy of 63.8 years; in 1980 the projected life expectancy for whites aged twenty was 72.7 years for the male, a gain of 10.5 years; and 79.7 for the female, a gain of 15.9 years. ${ }^{58}$ The comparable figures for nonwhites are lower, but the rate of improvement across the twentieth century has been better, especially for women. ${ }^{59}$ Thus, we see that even after we correct for infant mortality, the diminished life expectancy of the last century was marked enough to explain why contemporaries so seldom had occasion to talk about what we call the retirement income problem. If you chanced to outlive your productive years, you did not in general do it for very long.

But what of the relative handful who did need retirement support? The well-known pattern was one of reverse transfer. Within the family, the children, now mature, would support superannuated parents. For propertied persons, however, this image of reverse transfer conceals an important point. In the age of family-centered economic organization, the parents still owned the farm or the firm. In a sense that defies accounting precision but that is nevertheless worth emphasizing, when the elders received support from the children, they were living from their capital in the family enterprise - that enterprise to which the children would succeed when the elders died.

57. As late as 1907 ,

1 in about 7 newborns died in their first year of life, whereas in 1977, 1 in 67 died then; between the ages of one and four, 1 in about 17 of those born in 1907 died, whereas 1 in about 360 died among those born in 1977 - representing a 21 -fold reduction.

J. URQuHART \& K. HeIlMANN, Risk WATCh: THE OdDS OF LIFE 6 (1984).

58. INHERITANCE IN AMERICA, supra note 4, at 149.

59. Id. 
Now return to the late twentieth century to see what has changed. Not only have the demographics altered so that the elders are routinely surviving for long intervals beyond their years of employment, but in consequence of the transformation in the nature of wealth, their property has taken on a radically altered character. That family farm or family firm that was the source of intrafamilial support in former times has become ever more exceptional. Most parental wealth (apart from the parents' own human capital) now takes the form of financial assets, which embody claims upon those large-scale enterprises that have replaced family enterprise.

\section{B. Pension Wealth}

In propertied families, today's elderly no longer expect much financial support from their children. The shared patrimony in farm or firm that underlay that reverse transfer system in olden times has now largely vanished. Instead, people of means are expected to foresee the need for retirement income while they are still in the workforce, and to conduct a program of saving for their retirement. Typically, these people have already undertaken one great cycle of saving and dissaving in their lives - that program by which they effected the investment in human capital for their children. Just as that former program of saving was oriented toward a distinctively modern form of wealth, human capital, so this second program centers on the other characteristic form of twentieth-century wealth, financial assets.

A priori, we might expect that individuals would be left to save for retirement without government guidance, much as they are left alone to save and spend for other purposes, but that has not been the case. Instead, the federal government has intervened by creating irresistible tax incentives to encourage people to conduct much or most of their retirement saving in a special mode, the tax-qualified pension plan.

There are three crucial advantages to conducting retirement saving through a tax-qualified pension plan. First, most contributions to the plan are tax-deferred. ${ }^{60}$ When my employer contributes to a qualified pension or profit-sharing plan on my behalf, or when I contribute to a defined contribution plan such as a $401(\mathrm{k})$ or, in the case of academic personnel, a 403(b), I am saving with pretax dollars. If I am in the 25percent bracket, the Treasury is contributing to my pension savings plan 25 cents in foregone taxation for my 75 cents in foregone consumption.

The second great tax advantage is that the earnings on qualified 
plan investments accrue and compound on a tax-deferred basis. ${ }^{61} \mathrm{It}$ is not until the employee retires and begins to receive distributions of his pension savings that he pays income tax on the sums distributed. The third major advantage associated with pension taxation is that, because most retirees have lower taxable income in their retirement years than in their peak earning years, they find that distributions from pension accounts are usually taxed at lower marginal rates. As the progressivity of the income tax has abated in recent years, however, this attribute of the system has become less significant.

As a matter of tax policy, it is open to serious question whether Congress should be granting the level of tax subsidy for pension saving that it now does, ${ }^{62}$ but that is a topic for another day. The present point is that the tax attractions of conducting retirement saving through the medium of a tax-qualified pension plan are simply overwhelming. These advantages explain why employers incur the regulatory costs incident to sponsoring these plans; and why employees, especially those in higher tax brackets, ${ }^{63}$ prefer to take compensation in the form of pension saving rather than cash wages. The private pension system - this two-trillion-dollar savings scheme - is tax driven. ${ }^{64}$

\section{Annuitization Eliminates Succession}

From the standpoint of our interest in the patterns of family wealth transmission, what is especially important about the pension system is that it has been deliberately designed to promote lifetime exhaustion of the accumulated capital. The same body of federal law that encourages pension saving also tries to ensure that pension wealth will be consumed over the lives of the worker and his spouse. ${ }^{65} \mathrm{I}$ do not mean to say that the federal policy in favor of lifetime consumption of retirement savings cannot be defeated for particular clients using appropriately designed plans; indeed, that is one of the major

61. See I.R.C. § 501(a) (West Supp. 1987).

62. See generally Wolk, Discrimination Rules for Qualified Retirement Plans: Good Intentions Confront Economic Reality, 70 VA. L. REv. 419 (1984).

63. Private pension coverage is strongly skewed to employees in the higher tax brackets. Whereas $24.3 \%$ of persons earning less than $\$ 5000$ per year in 1983 had pension coverage, $84.9 \%$ of those earning \$50,000 and over in that year had pension coverage. E. ANDREWS, THE Changing Profile of Pensions in America 52 (1985). For an account of why the antidiscrimination norm of federal tax policy fails to achieve breadth of coverage, see Wolk, supra note 62.

64. See R. Ippolito, supra note 47 , at 16-35.

65. See I.R.C. $\S 401(a)(9)(A)(i i)$ (West Supp. 1987) (pension trust not tax-qualified "unless the plan provides that the [employee's] entire interest ... will be distributed ... over the life of such employee or over the lives of such employee and a designated beneficiary ....."). 
avenues of tax and estate planning for the carriage trade that has arisen with the pension system. ${ }^{66} \mathrm{My}$ point is simply that, in the main, the federal policy achieves its goal, and only a negligible fraction of pension wealth finds its way into intergenerational transfer.

The mechanism by which pension wealth is consumed is annuitization. Just as life insurance is insurance against dying too soon, annuitization insures against living too long. Annuitization allows people to consume their capital safely, that is, without fear of running out of capital while still alive. Annuitization requires a large pool of lives, which is achieved by various methods of aggregating the pension savings of many workers. Sometimes the employer runs the pool, sometimes an intermediary such as an insurance company or (for multiemployer plans) a labor union. Annuitization requires assets that can be liquidated predictably as distribution requires. That is a trait characteristic of financial assets. Annuitization is wonderfully effective in allowing a person to consume capital without fear of outliving his capital, but the corollary is also manifest: Accounts that have been annuitized disappear on the deaths of the annuitants. Not so much as a farthing remains for the heirs. ${ }^{67}$

From this brief tour of the private pension system, I hope it will be clear why I place this topic alongside my other main topic, wealth transfer by means of investment in human capital, as the two central chapters in what $I$ have been calling the twentieth-century revolution in family wealth transmission. Both are developments of enormous magnitude, and both lead away from traditional wealth transfer on death. Propertied parents used to live from their patrimony in farm or firm and then transmit the patrimony at death. Modern parents tend to possess nontransmissible human capital more than older forms of property. Using their human capital to create lifetime income streams, modern parents now undertake two cycles of saving and dissaving, one for the children's education, the other for retirement. The investment in the children necessarily occurs in the parents' lifetimes. And especially when the retirement saving program is channelled through the enticing format of the qualified pension plan, the pressures for annuitization cause this enormous component of modern family wealth to be largely exhausted upon the parents' deaths. Transfer on death, the fundamental pattern of former times, is, therefore, ceasing to charac-

66. See, e.g., Simmons, IRAs, IRD and Qualified Plans - What ACPC Fellows Should Know About Employee Plan Payout Rules, 12 ProB. Notes 294 (American College of Probate Counsel, 1987).

67. Unless the plan offers and the participant elects a mode of annuitization that provides a guaranteed income stream (typically 10 or 20 years); in such cases, successors take the remainder of the stream if the annuitants die within the period. 
terize the dominant wealth transmission practices of the broad middle classes.

\section{Wealth TRANSFER ON DEATH}

\section{A. The Carriage Trade}

Decline is not extinction. The trust-and-estate bar survives, and the main reason is the carriage trade. As I said at the outset of this article, the revolution in family wealth transmission stops short of really substantial accumulations of wealth. The carriage trade is hugely important. One study of data for the half century from the early 1920 s through the late 1960 s focused on the top half of the top one percent of wealth holders. Throughout the period the share of national wealth was consistently above $20 \% .68$ Another study reporting on more recent data indicates that as of 1983 , the top 840,000 households each possessed wealth of $\$ 1.4$ million or more. According to computations that originated in Democratic party policy circles and whose accuracy has been questioned, this group of households accounted for $42 \%$ of the country's net wealth. ${ }^{69}$ These calculations presuppose that financial instruments, business interests, and real property are the only important components of wealth. Because this way of measuring wealth excludes the capitalized value of the income streams generated by human capital, and because it excludes the capitalized value of the private-pension and Social Security income streams, it materially overstates the disparity between the top wealth holders and the rest of the populace. ${ }^{70}$ These calculations also overlook what economists call the life-cycle effect: University of Michigan law students who will have six-figure incomes within a decade are currently reckoned as paupers. Nevertheless, the underlying point is undeniable. The top sliver of wealth holders is indeed very affluent, and among them the need for estate planning services will continue unabated.

To be sure, the transformation in the nature of property has affected great wealth holders as well as small. The family enterprise is less common, the portfolio of financial assets more prevalent. But the

68. Smith \& Franklin, The Concentration of Personal Wealth, 1922-1969, 64 AM. EcoN. REV. 162, 163-65 (1974).

69. Democratic StafF of The Joint Economic Committee, U.S. Congress, The ConCENTRATION OF WEALTH IN THE UNITED STATES: TRENDS IN THE DISTRIBUTION OF WeAlth AMONG AMERICAN Families 23-26 (1986) [hereinafter TRENDS IN WEALTh DistriBUTION]. For skepticism about this computation, see Eubank, A.D. 2001: Estate Planning in the Future, in The Twenty-First ANNuAl Philip E. Heckerling Institute on Estate PlanNing ch. 20, at 20-4 to 20-11 (J. Gaubatz ed. 1987).

70. See Boskin, An Economist's Perspective on Estate Taxation, in DEATH, TAXES AND FAMily Property: Essays aNd American Assembly Report 56, 57-58 (E. Halbach ed. 1977). 
changes in the patterns of wealth transfer that I have been describing for the middle and upper-middle classes are much less important for the very well-to-do. As regards the investment in human capital that preoccupies the middle classes, I have already made the point that because the amount of educational investment that can be made in any one set of children is constrained, the educational expenditures that loom so large for conventionally propertied families constitute for $\mathrm{dy}$ nastic wealth holders a much smaller drain on family wealth.

Likewise, the qualified pension-plan account is not an acceptable vehicle for great fortunes. Only earned income, not investment income, is eligible for qualified-plan tax deferral. Furthermore, section 415 of the Internal Revenue Code sets ceilings on the amount of saving that anyone is allowed to do within a qualified-plan account. Currently, the ceiling is $\$ 30,000$ per year in saving for defined contribution plans; for defined benefit plans, the cap applies when the annual benefit reaches $\$ 90,000$ per year. ${ }^{71}$ For people of middle-class and even upper-middle-class means, these ceilings scarcely pinch, but for the really well-to-do, such ceilings represent a significant barrier. The simple truth is that dynastic wealth cannot be stuffed into a pension account.

\section{B. The Middle Market}

Turning to the middle and upper-middle classes, we can identify a variety of factors that explain why the trust-and-estate lawyer survives even where he can no longer thrive. The personal circumstances of some propertied decedents fall outside the prototype that I have described - for example, people who are childless, or whose employers did not offer much opportunity for pension saving. But even people who fully experience the two cycles of saving and dissaving that I have described will have additional property outside the pension accounts. This wealth is likely to comprise both financial assets and real estate, especially residential real estate, although much of that real estate is held in probate-avoiding forms of concurrent ownership. As of 1983, residential realty accounted for about $30 \%$ of the gross wealth of American families. ${ }^{72}$ Data from 1975 indicates that over $70 \%$ of Americans aged between sixty-three and sixty-nine owned their homes; almost $80 \%$ of the elderly owned their homes free of mortgage. ${ }^{73}$ I do not have good data on the nonresidential wealth of the

71. I.R.C. $\$ 415(b)(1)(A)$, (c)(1)(A) (West Supp. 1987).

72. TRENDS IN Wealth Distribution, supra note 69, at 20-21.

73. A. Munnell, The Economics of Private Pensions 27 (1982) (citing Social Security Administration data). 
elderly, but I would certainly stipulate that their aggregate holdings are extensive.

Whether the relative affluence of the present generation of American elders is likely to be reproduced in the future is a harder question. Americans who came of age during and shortly after World War II experienced unexampled prosperity. The generation that won the war profited hugely from the fifteen-year Pax Americana that endured roughly from 1952 to 1967 . As the war-torn economies of Europe and the Far East rebuilt, America's comparative advantage declined, and our wealth has declined apace. Furthermore, the generation that benefitted from the one-time windfall of postwar prosperity also received the one-time windfall of the huge increase in Social Security transfer payments. It is worth remembering that as late as 1950 , the average monthly Social Security benefit for a retiree was only $\$ 29.03 .74$ In October 1987 that benefit was $\$ 491.75 .75$ The present generation of elderly voted itself a multi-trillion-dollar treat in the form of transfer payments extracted from succeeding generations. ${ }^{76}$ We should not be surprised that some of these people have some wealth left over to transmit at death.

Quite apart from whether future generations of elderly will be able to accumulate as much wealth as the present generation, it is important to recognize that much of the nonpension wealth that survives for transfer on death in middle- and upper-middle-class families is deeply affected by another great trend that has fundamentally diminished the lawyerly role in wealth transfer on death. I refer to the explosive growth in the use of nonprobate modes of transfer. Residential real estate is widely held in joint tenancy, under which a death certificate suffices to clear title without probate or other court proceedings. The more interesting phenomenon is the rise of the mass will substitutes that employ noncourt transfer systems - life insurance, pension accumulations prior to annuitization, POD accounts, joint accounts, and so forth. The numbers for life insurance alone are staggering. In 1986, American insurers had $\$ 6.72$ trillion of insurance in force, averaging $\$ 81,200$ per insured family; payments on death in that year

\section{Id. at 13 .}

75. Social Security in Review, Soc. Security BULL., Jan. 1988, at 2, 3.

76. Social Security has been described as a "Ponzi scheme," because the first generation receives benefits without having had to finance the retirement of its immediate predecessors. ...

... In contrast, middle-income household heads in the cohort to be born in 1990 are projected over their lifetimes to lose, on net, roughly $\$ 60,000$ in present value as a consequence of participating in Social Security.

Kotlikoff, Deficit Delusion, PUB. INTEREST, Summer 1986, at 53, 62. 
amounted to $\$ 19.5$ billion. ${ }^{77}$

The financial intermediaries who market financial assets (especially insurance companies and banks, but also investment companies, brokerage houses, stock issuers, and others) have taken to offering transfer-on-death services because they have a comparative advantage in doing so.

Financial intermediation is, as the term signifies, intrinsically administrative. Administrators intermediate between savers and borrowers, between passive owners and active users of capital. Pooling wealth and servicing the resulting liabilities involves recurrent transactions and communications. Once a bureaucracy appropriate to such tasks is in operation, only a scant adaptation is necessary to extend its functions and procedures to include the transfer of account balances on death. ${ }^{78}$

The main financial intermediaries have become powerful free-market competitors, competing against the probate system in arranging for wealth transfer on death.

The nonprobate system takes on a heightened significance when viewed from the perspective of the themes that I have been sounding in this article. Even when middle-class or upper-middle-class people emerge from their two cycles of saving and dissaving in possession of other wealth, and even when they hold that wealth until death, much of it - indeed most of it - now passes to survivors with little or no need for lawyer-administered transfer-on-death services. I do not mean to imply that lay persons are well advised to do their own estate planning through the medium of the nonprobate system. Quite to the contrary, I think that one of the worst consequences of the nonprobate system is that it tempts people into the mistake of thinking that avoiding probate is the equivalent of estate planning. Lay persons rarely understand the range of contingencies that can arise in the wealth transfer process - for example, issues like lapse; and the nonprobate system often handles those contingencies less well than the probate process. ${ }^{79}$

Nonprobate property is, of course, still subject to the federal transfer taxes, ${ }^{80}$ but the drastic 1981 reduction in those taxes has diminished the demand for estate planning services among the middle and upper-middle classes.

Apace with the decline in demand for lawyer-assisted planning

77. AMERICAN COUNCIL OF LIFE INSURANCE, 1987 LIFE INSURANCE FACT BOOK UPDATE 4 (1987).

78. Langbein, The Nonprobate Revolution and the Future of the Law of Succession, 97 HARV.

L. REv. 1108, 1119 (1984).

79. Id. at $1135-40$.

80. See I.R.C. $\S \S 2001$ et seq. (1982 \& West Supp. 1987). 
services has been the diminution of demand for lawyer-assisted transfer services even when probate or administration of an estate must occur. The probate reform movement of the $1960 \mathrm{~s}$, epitomized in the Uniform Probate Code's provisions for simplified probate ${ }^{81}$ and for nonadministration of very small estates, ${ }^{82}$ has further limited the scope for court-operated transfer services. ${ }^{83}$

A comprehensive account of the patterns by which inter vivos wealth transfers now displace transfers that in former times occurred on death would also embrace the huge twentieth-century increase in the divorce rate. Dissolution upon divorce has replaced dissolution upon death as the predominant mode of terminating a marriage. ${ }^{84}$ The property transfers that divorce precipitates, both transfers to spouses and transfers to children, supplant in some measure a wealth transfer process that used to occur through succession.

\section{CONCLUSION}

Increasingly, estate planning services for the middle and uppermiddle classes have the quality of contingency planning. The client is motivated largely by concern to make arrangements for his family in the unlikely event that he should die prematurely. He does not expect property actually to pass under the instrument he executes. In this sense, he views his estate plan somewhat like his term life insurance policy. It is catastrophe insurance, worth having even though it is unlikely to be needed. ${ }^{85}$

The modern expectation is that for middle-class wealth, the main

81. UNIf. Probate CODE $\$ \$ 3-301$ et seq., 8 U.L.A. 245 (1982).

82. UNif. Probate CODE $\S \S 3-1201$ to 3-1204, 8 U.L.A. $412-16$ (1982).

83. For empirical data on the levels of probate (including administration of intestate estates) from an extensive study conducted under the auspices of the American Bar Foundation, see Stein \& Fierstein, The Demography of Probate Administration, 15 U. BALT. L. REv. 54, 61 (1985). In a five-state study conducted in the mid-1970s, "the average percentage of decedents' estates that underwent estate administration ranged from twenty percent in California to thirty-four percent in Massachusetts . . . ." Id. (Compare earlier data of this sort, conveniently collected in Fletcher, Probate in England: A Blueprint for the Future? (Book Review), 46 WASH. L. REV. $619,624 \&$ n.14 (1971).) Simplified probate and administration procedures significantly reduced the percentage of estates requiring full-dress administration. Stein \& Fierstein, supra, at 75-77. The authors emphasize that a key finding of their study is that "relatively few decedents leave a substantial estate requiring judicial administration." Id. at 87.

84. The official comment to the Uniform Marital Property Act reports that, of marriages terminated in $1979,42.77 \%$ were terminated by death, compared to $57.23 \%$ that ended in divorce. UNIf. Marital Property ACt prefatory note (1983).

85. The contingent quality of the estate plan must help explain the mind-set that inclines many a client to resist paying for legal services in the estate planning department at rates comparable to those charged down the hall in the corporate or litigation departments. Since the client does not plan to use this estate planning scheme to transfer wealth within his family if he lives as long as he expects, he feels that he should not have to pay real money for it. 
intergenerational transfer will occur in mid-life, in the form of educational expenditures. The characteristic wealth of later years, the income streams from the public and private pension systems, do not give rise to heirship. Thus, wealth transfer on death is ever less important to the middle classes; and when it does occur, it is ever more likely to be channelled through the nonprobate system. These are the great forces that underlie the decline of the trust-and-estate bar.

So long as the carriage trade abides, the trust-and-estate bar will not go the way of the blacksmith, but the precipitous decline of the middle-class market is likely to continue. From the revolutionary changes that have affected the family property relations of the middle and upper-middle classes, only table scraps remain for the trust-andestate lawyer. The days of routine, lawyer-guided wealth-transfer-ondeath for the middle classes have largely passed. 